2. Новіков Б. В. Філософрія як теорія і методологія творчості // Вісник НТУУ —КПІІІ. Філософрія. Психологія. Педагогіка. Випуск 2.2011. С. 108-113.

3. Палій А. А. Диференціальна психологія : навч. посіб. К. : Академвидав, 2010. 432 с. URL: http://pidruchniki.com/14210923/psihologiya/zdatnist_tvorchosti_zvyazki_tvorchosti_intelektu.

4. Психологический словарь / [под ред. В. П. Зинченко, Б. Г Мещерякова]. - 2-е изд., перераб. и доп. М. : ПедагогикаПресc, 1999. 440 c.

5. Соціолого-педагогічний словник [за ред. В. В. Радула]. К. : «Екс Об», 2004. 304 с.

6. Топчій І. Філософський аспект проблеми творчості: зарубіжний досвід // Молодь і ринок №1 (72), 2011 C 136-140.

7. Філософія: Навчальний посібник / І. Ф. Надольннй, В. П. Андрушенко та ін.; За ред. І. Ф. Надольного. К.: Вікар, 1997. $584 \mathrm{c}$.

8. Філософський енциклопедичний словник : енциклопедия / НАН України, Ін-т фрілософії ім. Г. С. Сковороди ; голов. ред. В. І. Шинкарук. Київ: Абрис, 2002. 742 с.

9. Філософський словник / за ред. В. І. Шинкарука. 2-е вид., перероб. доп. К.: Головна редакція УРЕ, 1986. 800 с.

\title{
References
}

1. lefimenko S.M. (2013). Vyznachennia poniattia intelektu u riznykh kontseptsiiakh psykholoho-pedahohichnykh doslidzhen. Naukovi zapysky. Seriia : Pedahohichni nauky. Kirovohrad. Issue. 121, 90-95 [in Ukrainian].

2. Novikov, B.V.(2011). Filosofiia yak teoriia i metodolohiia tvorchostiю Visnyk NTUU KPI. Filosofiia. Psykholohiia. Pedahohika. Vypusk 2, 108-113 [in Ukrainian].

3. Palii, A.A. (2010). Dyferentsialna psykholohiia: navch. posib. K.: Akademvydav [in Ukrainian].

4. Psykholohycheskyi slovar. (1999). M.,: Pedahohyka-Press [in Russian].

5. Sotsioloho-pedahohichnyi slovnyk. (2004). K. Eks Ob [in Ukrainian].

6. Topchii, I. (2011). Filosofskyi aspekt problemy tvorchosti: zarubizhnyi dosvid. Molod i rynok, 1 (72), $136-140$ [in Ukrainian].

7. Filosofiia: Navchalnyi posibnyk. (1997). Za red. I.F. Nadolnoho. K, Vikar [in Ukrainian].

8. Filosofskyi entsyklopedychnyi slovnyk: entsyklopedyia. (2002). Kyiv: Abrys [in Ukrainian].

9. Filosofskyi slovnyk. (1986). K. Holovna redaktsiia URE [in Ukrainian].

Стаття надійшла до редакції 23.08.2019 р.

Курило Володимир Іванович доктор юридичних наук, професор, завідувач кафедри адміністративного та фрінансового права Національного університету біоресурсів природокористування України ORCID: 0000-0003-1268-801X volodymyr.kurylo@gmail.com

Світличний Олександр Петрович. доктор юридичних наук, доцент, профресор кафедри цивільного та господарського права,

Національний університет біоресурсів і природокористування України ORCID: 0000-0003-0485-3804 a.svetlichnyj@ukr.net Курило Людмила Ізидорівна. доктор економічних наук, професор, профресор кафедри маркетингу та управління бізнесом

НУ «Києво-Могилянська академія» ORCID: 0000-0001-5131-0146 Lyudmila.kurylo@gmail.com

\section{ПРОФЕСІЙНА ДІЯЛЬНІСТЬ ЯК ЧИННИК ФОРМУВАННЯ КУЛЬТУРИ ОСОБИСТОСТІ}

Мета статті полягає в аналізі професійної діяльності людини та визначенні основних етапів, критеріїв та показників, що впливають на формування культури особистості. Методологія дослідження становить загальнонаукові теоретичні методи аналізу, синтезу та абстрагування, що дозволило простежити формування та розвиток культури особистості під час здійснення професійної діяльності. Наукова новизна пов'язана з визначенням теоретичних і практичних аспектів формування культури особистості у процесі становлення та розвитку її професійної діяльності. Висновки. У результаті дослідження встановлено, що культура особистості тісно пов'язана з професійною культурою, яка є основою професійної компетентності, охоплює індивідуально відпрацьовані стратегії, засоби та прийоми розв'язання різноманітних завдань професійної діяльності. Високий рівень розвитку культури особистості становить зміст та глибину професійного інтересу, без якого неможливим стає оптимальна відповідність фахівця його професії. Формування культури особистості у професійній діяльності забезпечується також і високим рівнем професійно-творчої спрямованості, що відображає єдність інтересів і творчого потенціалу працівника.

(С) Курило В. І., 2019

(С) Світличний О. П., 2019

() Курило Л. І., 2019 
Ключові слова: професійна діяльність, культура, професійна культура, особистість, суспільство.

Курило Владимир Иванович, доктор юридических наук, профрессор, заведующий кафедрой административного и финансового права Национального университета биоресурсов и природопользования Украины; Светличный Александр Петрович, доктор юридических наук, доцент, профрессор кафедры гражданского и хозяйственного права, Национальный университет биоресурсов и природопользования Украины; Курило Людмила Изыдоровна, доктор экономических наук, профрессор, профессор кафедры маркетинга и управления бизнесом НУ «Киево-Могилянская академия»

Профессиональная деятельность как фактор формирования культуры личности

Цель статьи заключается в анализе профессиональной деятельности человека и определении основных этапов, критериев и показателей, влияющие на формирование культуры личности. Методология исследования составляет общенаучные теоретические методы анализа, синтеза и абстрагирования, что разрешит проследит формирование и развитие культуры личности во время осуществления профессиональной деятельности. Научная новизна связанные с определением теоритических и практических аспектов формирования культуры личности в процессе становления и развития ее профессиональной деятельности. Выводы. В результате исследования установлено, что культура личности тесно связана с профессиональной культурой, которая является основой профессиональной компетентности, охватывает индивидуально отработанные стратегии, средства и приемы решения разносторонних задач профессиональной деятельности. Высокий уровень развития культуры личности составляет содержание и глубину профессионального интереса, без которого невозможным становится оптимальная ответственность специалиста его профессии. Формирование культуры личности в профессиональной деятельности обеспечивается также и высоким уровнем профессионально-творческой направленности, что отражает единство интересов и творческого потенциала работник.

Ключевые слова: профессиональная деятельность, культура, профессиональная культура, личность, общество.

Kurylo Volodymyr, Doctor of Science of Law, Professor, the Department of Administrative and Financial Law, National University of Life and Environmental Sciences of Ukraine, Kyiv, Ukraine; Svitlychnyy Oleksandr, Doctor of Science of Law, Associate Professor, Professor of Department of Civil and Commercial Law, National University of Life and Environmental Sciences of Ukraine; Kurylo Lyudmila, Doctor of economics, professor, Professor of Marketing and Business Management National University "Kyiv-Mohyla Academy"

Professional activity as a factor of formation of personal culture

The purpose of the article is to analyze the professional activity of the person, the definition of the main stages, criterion indicator, affecting the formation of a person's culture. The research methodology of research consists of the general scientific theoretical methods of analysis, the synthesis of the abstractions, which allowed to trace the formation and development of a person's culture during the period of professional activity. Scientific novelty is connected with the definition of theoretical and practical aspects of the formation of culture and personality in the process of becoming that development of its professional activities. Conclusions As a result of the study, it has been established that a person's culture is closely linked with professional culture, which is the basis of professional competence, covers individually worked out strategies, tools and techniques for solving various tasks of professional activity. The high level of development of a person's culture is the content and depth of professional interest, without which the optimal correspondence of the specialist of his profession becomes impossible. Formation of a person's culture in professional activity is also ensured by a high level of professional-creative orientation, reflecting the unity of interests and creativity of the employee.

Key words: professional activity, culture, professional culture, personality, society.

Актуальність теми дослідження. Важливість професійної діяльності як чинника формування культури особистості зумовлена сучасними запитами ринку праці, створення умов до отримання загальних знань і формування вмінь і навичок відповідно до освітньо-кваліфікаційного рівня, $є$ проявом і показником їхньої професійної компетентності та готовності до професійної діяльності на ринку праці. Тому, аналіз можливостей професійного середовища, яке є частиною міжлюдських відношень, сприйняття та усвідомлення учасниками різних форм праці, формування відношення до праці, дозволяє розглянути її як професійну діяльність особистості, як елемента професійної культури. Унікальність профресійного середовища обумовлена також тим, що передача професійного досвіду здійснюється в реальних ситуаціях професійної діяльності людини, забезпечується виконанням комплексу взаємопов'язаних функцій (адаптаційної, інформаційної, мотиваційно-стимулюючої, контрольно-регулювальної, професійної диференціації, соціальної інтеграції), якість яких залежить від ряду факторів і умов, етапів, критеріїв та показників, що складаються як стихійно, так і цілеспрямовано, що в цілому впливає на загальний розвиток особистості, і, зокрема, культуру особистості. Тому висвітлення цих питань потребує їх подальшого перегляду, аналізу і розв'язання.

Стан наукової розробки. Аналіз наукових досліджень засвідчує, що проблема професійної діяльності як чинника формування культури особистості набула в психології, педагогіці, фрілософії, юриспруденції, економіці особливого статусу і досліджувалась з різних точок зору багатьма вітчизняними та зарубіжними науковцями: А. Баталова, О. Власка, А. Дудалової, Є. Зеер, Н. Костенко, А. Кухарчук, В. Лях, В. Оссовького, І. Сабатовської, А. Широкової та інші. Невирішеними залишаються питання за якими виникнення професійної діяльності як чинника фрормування культури особистості є продуктом інституціонального (економічного, правового, соціального, інтелектуального та ін.) розвитку.

Виклад основного матеріалу. Під культурою особистості слід розуміти як досягнення особистості певної гармонії, що дає їй повноцінне соціальне життя і працю, а також особистісний психологічний комфорт. Умовно можна виділити наступні напрямки базової культури особистості: культура життєвого самовизначення; культура сімейних відносин; економічна культура; культура праці; політична, демократична і правова культура; інтелектуальна, моральна культура і культура спілкування; екологічна культура; художня культура; фізична культура, тощо.

В умовах сучасної соціокультурної ситуації заявляти про вирішальну чи головну роль якогонебудь напрямку базової культури особистості буде не зовсім коректно. Професійна діяльність та професійна культура $€$ на нашу думку тими, які так само впливають на процес становлення особистості. Зокрема, на думку І. Сабатовської, особливе значення на фрормування культури особистості, має 
професійна культура. Вона посідає все більше місце і як предмет дослідження, і як фактор, важливий для пояснення, розуміння поведінки працівників, і особливо майбутніх фрахівців, як людей, що мають володіти спеціальними знаннями й навичками в будь-якій галузі, бути висококваліфікованими фрахівцями із широкою ерудицією та високим загальнокультурним рівнем відповідно до глобальних викликів сучасності [12].

Професійна культура у сучасному її розумінні - феномен складної структури, визначення якої потребують теорія і практика вищої школи, оскільки з неї має виходити організація навчальновиховного процесу, формування і розвиток загальної культури студентів, їх професійна підготовка та професійне становлення [3]. Отже, культура особистості фрормується завдяки основним складовим її професійних досягнень. Так, за джерелом [1, 58] основними складовими професійних досягнень можна вважати: освіченість; системність і аналітичність мислення (уміння прогнозувати розвиток ситуації і передбачати результат рішень, уміння мислити масштабно й реалістично одночасно); комунікативні уміння й навички ефективної міжособистісної взаємодії; високий рівень саморегуляції (уміння керувати своїм станом, стійкість до стресів); ділова спрямованість (активність, наполегливість і цілеспрямованість на прийняття рішень, уміння розв'язувати нестандартні проблеми й завдання, прагнення до постійного підвищення професіоналізму); ясна Я-концепція, реалістичне сприйняття своїх здібностей і можливостей, адекватна та висока самоповага.

Відповідно, процес формування культури особистості є складним і багато в чому залежить від соціалізації особистості, в процесі якої утворюються ті якості та властивості, які формують культуру особистості. Під соціалізацією автори розуміють процес засвоєння індивідом соціального досвіду, традицій, звичаїв, вірувань, цінностей, ролей та очікувань, властивих певній культурі або соціальній культурі $[6,518]$.

Професійна діяльність особистості проходить етапи професійного становлення. Професійне становлення - це формування професійної спрямованості, компетентності, соціально значущих та професійно важливих якостей і їх інтеграція, готовність до постійного професійного зростання, пошук оптимальних прийомів якісного і творчого виконання діяльності у відповідності до індивідуальнопсихологічних особливостей людини $[5,30]$. Зокрема, під професійним становленням фрахівця розуміють процес прогресивної зміни його особистості внаслідок соціальних впливів, професійної діяльності і власної активності, спрямованої на самоудосконалення і самоздійснення. Становлення обов'язково передбачає потребу у розвитку і саморозвитку, можливість і реальність її задоволення, а також потребу у професійному самозбереженні $[5,29,58]$.

Культура професійної діяльність повинна, на нашу думку, включити культуру норм і правил, зокрема: норми професійної компетентності, культуру професійних мотивів, правильність, точність, порядок, самодостатність, відповідальність тощо. Відповідно, на стадії професіоналізації професійний розвиток особистості починає домінувати над особистісним і визначати його, та $є$ одним із основних складових у фрормуванні культури професійного спілкування фрахівця та культури особистості взагалі.

Відповідно до Класифікатора професій професіоналами визначаються особи з високим рівнем знань у галузі фрізичних, математичних, технічних, біологічних, агрономічних, медичних чи гуманітарних наук, та необхідною класифікацією (з урахуванням кола та складності певних професійних завдань та обов'язків), що документально підтверджується [8].

У Законі України «Про освіту» визначено, освіта є основою інтелектуального, духовного, фрізичного і культурного розвитку особистості, її успішної соціалізації, економічного добробуту, запорукою розвитку суспільства, об'єднаного спільними цінностями і культурою, та держави [10]. Відповідно, головне завдання системи освіти полягає у формуванні у майбутніх фахівців, володіння навичками самоосвіти й самовиховання, вміти узгоджувати свої дії з діями інших учасників спільної діяльності, здатних до прийняття оптимальних рішень та творчості, що сприяють професійному становленню особистості, розвиткові індивідуальності майбутніх фахівців, формуванню у них професійних якостей та готовності до самостійного життя в суспільстві після завершення навчання. У проекті Національної стратегії розвитку освіти в Україні на 2012-2021 роки визначено основні напрями, пріоритети, завдання і механізми реалізації державної політики в галузі освіти у нових економічних і соціокультурних умовах, окреслено шляхи інтеграції освіти в європейський та світовий освітні простори [9].

В даний час основи як професійної, так і загальної культури закладаються всебічною підготовкою фахівця, яка, включає: фундаментальну методологічну й світоглядну підготовку; широку гуманітарну підготовку; теоретичну й практичну підготовку з профільних дисциплін; творчу підготовку за фрахом; підготовку в галузі науково-дослідної й дослідно-конструкторської роботи, формування навичок самостійної творчої діяльності. Зазначені головні напрями підготовки включають ряд взаємозалежних, більш часткових за змістом фрорм підготовки: економічну, математичну, соціологічну, соціальнопсихологічну, педагогічну, управлінську, правову, екологічну тощо. Їх обсяг і зміст орієнтовані на спеціальність і співвідносяться з потребами кожної конкретної галузі у суспільстві [11].

Сьогодні, професійна освіта, яку отримує людина (академії, коледжі, інститути, університети) характеризується формалізацією і регламентацією. Особливістю даного виду умов є їх змістовна однозначність, обумовлена освітніми стандартами, кількісна визначеність - навчальними дисциплінами плану, час і тривалість - навчальною програмою та розкладом. На нашу думку, саме ці характеристи- 
ки створюють переваги в чіткій організації освітнього процесу та одночасно орієнтують на важливість в освітній діяльності гранично широкого накопичення особистістю знань і уявлень (когнітивний компонент). Когнітивне спілкування має свою специфіку, майже завжди орієнтоване на майбутнє. У зв'язку 3 чим ці умови більшою мірою створюють можливості для «відтворення» знань, тобто - когнітивного компонента культури.

Актуальною стає культура розумової праці особистості, яка представляє собою духовну культуру людства, що включає в себе процеси і результати пізнання, осмислення і перетворення світу і себе. Виступаючи як суспільне явище, культура розумової праці відроджується, освоюється і відтворює кожну особистість індивідуально.

Формування культури особистості залежить також і від сфери професійної діяльності, її суспільної, соціальної значимості, вимоги до професіоналів закріплюються на різних рівнях: законами України, підзаконними нормативно-правовими актами, звичаями ділового обороту. Необхідність володіння відповідним набором знань, властивостей, характеристик, практичних навиків, завдяки яким, фрахівець, при виконанні службових повноважень, зможе виконувати ті чи інші функції, ту чи іншу діяльність, яка визнається професійною, при цьому істотну роль відіграватимуть соціальні мотиви: самоповаги, самовираження, самореалізації та самоосвіти, які реалізуються в спільній професійній діяльності

Отже, професійна діяльність фахівця є тим самим структурним ланцюгом або комплексною системою елементів, яка є своєрідним чинником формування культури особистості, а саме: професійне мислення, професійний інтерес, професійні знання, уміння, навички й здібності, професійний досвід, ступінь готовності особистості до конкретного виду діяльності, професійний світогляд, професійна майстерність, адаптованість до професійного середовища, професійна мораль тощо. Тобто, елементи професійної культури фрахівця знаходяться у співвідношенні з особистою культурою (саморозвитку, самоорганізації, динамічності, випереджаючого розвитку, співробітництва, еврістичності, єдності предметних і соціальних умов діяльності, відповідальності та психологічної комфортності) та спрямованими на її перетворення. Це дозволяє виявити ступінь стійкості старого, характерного для трудової культури працівників професійного середовища, відобразити прояв нового, адекватного ринкового типу культури праці.

Висновки. Отже, є підстави стверджувати, що професійна діяльність впливає на загальне формування культури особистості, оскільки вона, в умовах розвитку сучасного суспільства, пов'язана 3 тим, що професійна діяльність є основою існування соціальної, правової, економічної та культурної політики держави, яка впливає на якісне та вчасне виконання службових обов'язків та повсякденну реалізацію прав та обов'язків людини.

Професійна діяльність та культура особистості на сучасному етапі набуває міждисциплінарний характер, а поняття «професійна культура» вимагає уточнення з позицій особистої культури, яка реалізовується у творчій професійній діяльності, міра «відкритості» нового знання, вміння дотримуватися професійним правилам, нормам і традиціям, встановленим у відповідному професійному середовищі.

\section{תimepamypa}

1. Акмеологія з основами психології кар'єри: Навч.-метод. посібн. / О.М. Гавалешко. Чернівці: Рута, 2004. 84 с.

2. Баталов А. А. О некоторых моментах становления комплексного подхода к личности // Проблемы личности : материалы симпозиума. Москва, 1989. 520 с.

3. Власюк О. Структура професійної культури сучасного фахівця. URL file://C:/Users/admin/Downloads/Nznuoapp_2008_11_6.pdf (дата звернення: березень 2019).

4. Дудоладова А. В. Професійна культура особистості майбутнього фахівця. URL http://www.rusnauka.com/8_DNI_2009/Pedagogica/43385.doc.htm (дата звернення: березень 2019).

5. Зеер Э.Ф. Психология профессий: Учебн. пособие. 3-е изд., перераб. и доп. Москва: Академический Проект, Фонд «Мир», 2005. 336 с.

6. Кухарчук А. М., Лях В. В., Широкова А. Б. Человек и его профессия. Минск: Соврем. слово, 2006. 544 с.

7. Костенко Н. В., Оссовский В. Л. Ценности профессиональной деятельности. Київ, 1986. 151 с.

8. Національний класифікатор України (Класифікатор професій ДК 003:2010, затверджений Наказом Держспоживстандарту України від 28.07.2010 № 327. URL : https://zakon.rada.gov.ua/rada/show/va327609-10 (дата звернення: березень 2019).

9. Національна стратегія розвитку освіти в Україні на 2012-2021 роки // Міністерство освіти і науки, молоді та спорту України. URL: http://www.mon.gov.ua/images/files/news/12/05/4455.pdf. (дата звернення: березень 2019).

10. Про освіту Закон України. URL: https://zakon.rada.gov.ua/laws/show/2145-19 (дата звернення: березень 2019).

11. Сабатовська I. С. Професійна культура особистості: структура та критерії вимірювання. VI Международная научно-практическая конференция «Спецпроект: анализ научных исследований» (30-31 мая 2011г.). URL http://www.confcontact.com/20110531/so_sabat.htm (дата звернення: березень 2019).

12. Сабатовская И. С. Проблема профессиональной культуры в современной отечественной социологической литературе // Вчені зап. Харк. гуманіт. ун-ту «Нар. укр. акад.». 2002. Т. 9. С. 206-214.

\section{References}

[in Ukrainian].

1. Acmeology with the basics of career psychology: Educ.-method. Manual. (2004). O.M. Ghavaleshko (Ed.). Chernivci: Ruta

2. Batalov, A.A. (1989). About some aspects of the formation of an integrated approach to personality. Personality problems: symposium`s materials. Moscow [in Russian].

3. Vlasjuk, $O$. Structure of professional culture of a modern specialist. URL: file:///C:/Users/admin/Downloads/Nznuoapp_2008_11_6.pdf [in Ukrainian].

4. Dudoladova, A.V. Professional culture of future specialist personality. URL http://www.rusnauka.com/8_DNI_2009/Pedagogica/43385.doc.htm [in Ukrainian]. 